\title{
Miejsce języka polskiego w wielo- języcznym repertuarze uczniów szkół polskich na Litwie
}

\author{
The Place of the Polish Language in the Multilingual Repertoire \\ of Students from Polish Schools in Lithuania
}

|| Irena Masojć
Uniwersytet Witolda Wielkiego, Akademia Edukacji, Wilno
ORCID: 0000-0001-7492-946X

\begin{abstract}
The aim of the article is to clarify the place of the Polish language in daily communication and consciousness of young people, who attend Lithuanian schools with the Polish language of instruction, in respect to other languages (Lithuanian, Russian, English) learnt and used by them. The empirical material for the research was based on collected in 5 schools questionnaires (116 students) and interviews (37 students) from May to June 2019. The school students were requested to self-assess their own level of command of various languages, to reveal the way of their acquisition, areas of their use in communication and various activities considering new communication technologies as well as to express their own attitudes towards the languages mastered by them. The obtained data and the results of analysis of pupils' responses disclose a highly complex picture of co-existence of various languages in the multilingual competence of young people with a multi-dimensional role of the Polish language in it.
\end{abstract}

Key words: multilingualism, Polish language in Lithuania, youth sociolect, mother tongue, heritage language

Streszczenie: Celem artykułu jest wyjaśnienie, jakie miejsce wśród innych znanych i używanych języków zajmuje polszczyzna w komunikacji codziennej i w świadomości młodzieży, uczęszczającej do szkół z polskim językiem nauczania na Litwie. Podstawą materiałową niniejszych rozważań są przeprowadzone w 5 szkołach w maju-czerwcu $2019 \mathrm{r}$. badania z zastosowaniem metody kwestionariuszowej (116 uczniów) i metody wywiadu pogłębionego (37 uczniów). Uczniowie mieli dokonać samooceny znajomości różnych języków, ujawnić sposób ich akwizycji, zakres użycia w komunikacji i w różnych rodzajach aktywności, ze szczególnym uwzględnieniem nowych technologii komunikacyjnych, wyrazić swoje postawy wobec znanych języków. Wyniki analizy statystycznej danych oraz wypowiedzi uczniów ukazują złożony obraz współwystępowania różnych języków w wielojęzycznym repertuarze młodzieży, w którym miejsce polszczyzny nie jest jednoznaczne.

Słowa kluczowe: wielojęzyczność, polszczyzna litewska, socjolekt młodzieżowy, język ojczysty, język odziedziczony

\section{Wprowadzenie}

Trudności w nauczaniu języka polskiego w szkole polskiej poza granicami kraju wynikają głównie z jego ograniczonych funkcji komunikacyjnych 
w przestrzeni publicznej, w której dominuje inny język państwowy, oraz $\mathrm{z}$ jego funkcjonowania $\mathrm{w}$ stałym kontakcie $\mathrm{z}$ innym językiem (językami). Opis sytuacji na Litwie utrudnia fakt, że mamy tu do czynienia ze znacznie bardziej skomplikowaną sytuacją niż typowa bilingwalna, gdy język ojczysty/pierwszy/odziedziczony współwystępuje z językiem kraju osiedlenia. $\mathrm{Na}$ Litwie polszczyzna ściera się nie tylko z językiem państwowym (litewskim), lecz również nadal utrzymującym mocną pozycję językiem rosyjskim oraz coraz bardziej ekspansywnym językiem angielskim. Celem tego artykułu jest wyjaśnienie, jakie miejsce wśród innych znanych i używanych języków zajmuje polszczyzna w komunikacji codziennej i w świadomości młodzieży, uczęszczającej do szkół z polskim językiem nauczania na Litwie.

Procesy migracyjne, które w ostatnich dziesięcioleciach nabrały niebywałej intensywności, i zainteresowanie skupiskami dwujęzycznymi w różnych krajach spowodowały, że oprócz tradycyjnych pojęć język ojczysty i język obcy w polskiej glottodydaktyce pojawiło się zapożyczone z literatury anglojęzycznej pojęcie języka odziedziczonego (ang. heritage language), który zajmuje miejsce pośrednie między językiem ojczystym a językiem obcym. Jak uważają E. Lipińska i A. Seretny (2013, 4-5), z językiem ojczystym łączy go cel i sposób przyswajania: jest poznawany w dzieciństwie, w kontaktach z najbliższymi, stanowi dla użytkownika swoistą wartość kulturową jako nośnik przynależności do grupy etnicznej. Zdecydowanie węższy niż języka ojczystego jest jednak zakres jego użycia, który ogranicza się do sfery prywatnej. Pozbawiony jest on tych czynników, które wzmacniają rozwój polszczyzny w kraju: środowiska endolingwalnego i pełnego systemu edukacji. Podobieństwo z językiem obcym polega na tym, że w obu przypadkach użytkowników cechują nie w pełni rozwinięte kompetencje językowe, a zakres użycia obu kodów nie obejmuje wszystkich sfer życia. Różnica polega jednak na tym, że uczący się języka obcego nawet z nastawieniem pozytywnym zawsze traktują go z pozycji outsidera, podczas gdy użytkownicy języka odziedziczonego odbierają go jako „swój” kod, znak więzi grupowej i istotny wykładnik tożsamości. Oprócz tego w literaturze używa się pojęcia język drugi, pod którym ma się na myśli kod opanowany w naturalnym otoczeniu w drugiej kolejności po pierwszym, czyli ojczystym. Typologii tych dokonuje się głównie z perspektywy emigracyjnej i dlatego nie w pełni przystają one do takich wielojęzycznych środowisk autochtonicznych, jak mniejszość polska na Litwie.

Należy nadmienić, że również zdefiniowanie tak oczywistego pojęcia jak język ojczysty nie jest łatwe. Stosowane zazwyczaj w definicjach kryteria: pochodzenia (poznawany jako pierwszy), kompetencji (najlepiej opanowany), funkcji (używany we wszystkich zakresach), wewnętrznej identyfikacji (jest sposobem poznawania i interpretowania otaczającego świata), łatwiej przystają do środowiska jednojęzycznego lub przynajmniej sytuacji bilingwalnej, w której dwa języki poznaje się sukcesywnie. W tym drugim przypadku zdaniem Lipińskiej $(2003,15)$ :

Polonistyka. Innowacje

Numer 10, 2019 
Język ojczysty jest pierwszym poznawanym i „doświadczanym” (doznawanym) przez człowieka językiem, w którym się porozumiewa z otoczeniem. Ma on znaczący udział w poznawaniu świata i kształtowaniu struktury osobowości, sprawiając, że człowiek się z nim utożsamia, a w dorosłym życiu zazwyczaj w nim myśli, śni, liczy i modli się.

W warunkach wielojęzyczności symultanicznej, gdy dwa lub więcej kodów zostało przyswojonych jednocześnie, nie wszystkie wymienione cechy definicyjne się sprawdzają.

\section{Charakterystyka badanej grupy}

Badani uczniowie reprezentują najmłodsze pokolenie polskiej wspólnoty na Litwie. Według ostatniego powszechnego spisu ludności w 2011 r. Polacy stanowili 6,6\% (200,3 tys.) mieszkańców Litwy i byli największą mniejszością narodową (Rosjanie - 5,8\%, Białorusini - 1,2\%). Charakterystyczną cechą mniejszości polskiej w odróżnieniu od rosyjskiej, która jest rozsiana po całej Litwie, jest jej skupienie w jednym regionie - południowo-wschodniej Litwie (Wileńszczyzna) w przygranicznym pasie z Białorusią ${ }^{1}$. Mniejszość polska na Litwie jest wspólnotą autochtoniczną. Mimo że jej dzieje wywołują dotychczas wiele spekulacji, sami Polacy litewscy czują się pełnoprawnymi spadkobiercami wielowiekowego polskiego dziedzictwa kulturowego w tym kraju.

Polską wspólnotę narodową na Litwie od typowych wspólnot polonijnych różni to, że szkoły z polskim językiem nauczania funkcjonują w litewskim systemie oświaty ${ }^{2}$. Co prawda, uczy się w nich tylko 3,43\% ogółu uczniów na Litwie, co oznacza, że prawie połowa dzieci z polskich rodzin uczęszcza do innych szkół, najczęściej z litewskim językiem nauczania. W szkole z polskim językiem nauczania wszystkie przedmioty (z wyjątkiem języka litewskiego) są wykładane po polsku, chociaż w starszych klasach nauczanie staje się dwujęzyczne, ponieważ korzysta się z litewskich podręczników, a uczniowie są przygotowywani do państwowych egzaminów maturalnych zdawanych w języku litewskim. Nauka języka polskiego opiera się na podstawie programowej opracowanej na Litwie i skorelowanej z wytycznymi Ministerstwa Oświaty, Nauki i Sportu Republiki Litewskiej. Uczniowie uczą się w szkole czterech języków: od klasy I języka polskiego i litewskiego, od klasy II - pierwszego języka obcego, którym jest angielski, w starszych klasach mają możliwość wyboru drugiego języka obcego (rosyjskiego, niemieckiego, francuskiego itd.). W klasach szkoły podstawowej (V-VIII) uczniowie

\footnotetext{
${ }^{1}$ Największe skupiska Polaków mieszkają na obszarze rejonów wileńskiego (52,1\%), solecznickiego $(77,8 \%)$, trockiego $(30,1 \%)$ i święciańskiego (26\%). W centrum tego obszaru znajduje się Wilno, w którym w 2011 r. mieszkało 16,5\% Polaków. Udział polskiej mniejszości narodowej w demografii stolicy stopniowo się jednak zmniejsza, ponieważ największe miasto w kraju ciągle się rozrasta, przyciagając ludność z innych regionów Litwy.

2 Według danych Stowarzyszenia Nauczycieli Szkół Polskich na Litwie „Macierz Szkolna” na Litwie jest obecnie 51 placówek oświatowych, w których nauka odbywa się wyłącznie w języku polskim, oraz 25 - w których polskie klasy istnieją obok litewskich lub rosyjskich. 36 spośród tych szkół to szkoły średnie (gimnazja) kończące się maturą. W roku szkolnym 2018-2019 liczba uczniów uczących się po polsku w klasach 1-12 wynosiła 11114 osób. Maturę w 2017-2018 r. zdało 818 uczniów szkół z polskim językiem nauczania. Malejąca w ostatnich latach liczba uczniów w szkołach polskich jest odbiciem ogólnej tendencji w kraju spowodowanej emigracją i niżem demograficznym.
} 
tygodniowo mają 5 godzin lekcyjnych języka polskiego, 4 - języka litewskiego, 3 - języka angielskiego, na drugi język obcy, którym najczęściej jest rosyjski, przeznacza się tylko jedną lekcję tygodniowo. W klasach gimnazjalnych liczba godzin języków obcych pozostaje ta sama, zmianie ulega proporcja czasu przeznaczonego na naukę języka polskiego i litewskiego. Liczba lekcji języka polskiego zmniejsza się do 4, a liczba godzin lekcyjnych języka litewskiego zwiększa się do 6-7. Większy nacisk na naukę języka litewskiego podyktowany jest koniecznością przygotowania się do egzaminu maturalnego, którego wyniki w dużym stopniu mogą zaważyć na możliwości dostania się na finansowane przez państwo studia na uniwersytetach litewskich. Nauka języka polskiego kończy się tylko nieobowiązkowym szkolnym egzaminem maturalnym, który nie jest uwzględniany podczas rekrutacji na studia wyższe. Powoduje to, że język polski w ostatnich latach nauki w szkole zostaje odsunięty jako przedmiot na dalszy plan, nie wiąże się z nim bowiem większych profitów na przyszłość.

Młodzież uczęszczająca do szkół polskich na Litwie to osoby posługujące się na co dzień wymiennie czterema językami: polskim, litewskim, rosyjskim i angielskim. Znajomość tych języków zapewnia nie tylko nauka w szkole, lecz również kontakty rodzinne i środowiskowe oraz powszechny dostęp do Internetu, w którym możliwy staje się kontakt z każdym językiem oraz z osobami mówiącymi tym językiem na całym świecie.

Podstawą materiałową niniejszych rozważań są badania przeprowadzone w 5 szkołach maju-czerwcu 2019 r. metodą kwestionariuszową i metodą wywiadu pogłębionego. Udział w nich wzięli uczniowie III klasy gimnazjalnej mający około 18 lat (w zasadzie urodzeni w 2001 r.). Pisemne ankiety (dalej - A) wypełniło ogółem 116 osób, w wywiadach ustnych (dalej -W) wzięło udział 37 osób. Wybór szkół nie był przypadkowy, starano się uwzględnić różne uwarunkowania środowiskowe, aby ujawnić cechy wspólne w całości dla badanej populacji i ewentualne różnice, na które wpływ może mieć dominujące otoczenie językowe.

Tabela 1. Liczba badanych uczniów oraz charakterystyka szkół.

\begin{tabular}{|l|l|l|}
\hline Nazwa szkoły & $\begin{array}{l}\text { Liczba uczniów } \\
\text { uczestniczących } \\
\text { w badaniach }\end{array}$ & $\begin{array}{l}\text { Szczegółowe uwarunkowania } \\
\text { środowiskowe }\end{array}$ \\
\hline $\begin{array}{l}\text { Gimnazjum im. Jana Pawła } \\
\text { II w Wilnie (dalej - JPII) }\end{array}$ & $\begin{array}{l}\text { A }-25 \\
\text { W }-7\end{array}$ & $\begin{array}{l}\text { Szkoła wielkomiejska, dominują- } \\
\text { ce otoczenie - litewskojęzyczne. }\end{array}$ \\
\hline $\begin{array}{l}\text { Gimnazjum im. J.I. Kraszew- } \\
\text { skiego w Wilnie (dalej - } \\
\text { Krasz) }\end{array}$ & $\begin{array}{l}\mathrm{A}-27 \\
\text { W }-8\end{array}$ & $\begin{array}{l}\text { Szkoła wielkomiejska, dominują- } \\
\text { ce otoczenie - rosyjskojęzyczne. }\end{array}$ \\
\hline $\begin{array}{l}\text { Gimnazjum im. Parczew- } \\
\text { skiego w rej. wileńskim (da- } \\
\text { lej- Parcz) }\end{array}$ & $\begin{array}{l}\text { A }-28 \\
\text { W }-9\end{array}$ & $\begin{array}{l}\text { Szkoła małomiasteczkowa, do- } \\
\text { minujące otoczenie - polskoję- } \\
\text { zyczne. }\end{array}$ \\
\hline
\end{tabular}




\begin{tabular}{|l|l|l|}
\hline $\begin{array}{l}\text { Gimnazjum im. J. Śniadec- } \\
\text { kiego w rej. solecznickim } \\
\text { (dalej - Śniad) }\end{array}$ & $\begin{array}{l}\text { A }-23 \\
\text { W }-8\end{array}$ & $\begin{array}{l}\text { Szkoła małomiasteczkowa, do- } \\
\text { minujące otoczenie - rosyjsko- } \\
\text { języczne. }\end{array}$ \\
\hline $\begin{array}{l}\text { Gimnazjum im. T. Konwic- } \\
\text { kiego w rej. wileńskim (da- } \\
\text { lej-Kon) }\end{array}$ & $\begin{array}{l}\text { A - 13 }-6 \\
\text { W }\end{array}$ & $\begin{array}{l}\text { Szkoła wiejska, dominujące oto- } \\
\text { czenie - polskojęzyczne. }\end{array}$ \\
\hline
\end{tabular}

\section{Samoocena sprawności językowych}

W odpowiedzi na pytanie o znajomość języków w zasadzie uczniowie wymieniali 4 języki - polski, rosyjski, litewski i angielski (tylko kilka osób nie wymieniło angielskiego). W niektórych ankietach uczniowie się pochwalili znajomością nie tylko innych języków słowiańskich (ukraińskiego, białoruskiego) i zachodnioeuropejskich (niemieckiego, francuskiego, włoskiego, hiszpańskiego), lecz również takich egzotycznych, jak koreański, japoński, turecki. Uczniów cechuje więc wielojęzyczność w obu wymiarach, określanych we współczesnym anglojęzycznym dyskursie polityki językowej za pomocą dwu różnych terminów: multilingualism oraz plurilingualism, które nie mają jeszcze utrwalonych odpowiedników ani w języku polskim, ani $\mathrm{w}$ języku litewskim. Pierwsze pojęcie wiąże się ze zjawiskiem wielojęzyczności społecznej, czyli różnorodnością języków używanych w określonych regionach geograficznych, drugie zaś odnosi się do wielojęzyczności indywidualnej, która ujawnia się na poziomie kompetencji komunikacyjnej jednostki (por. KMPA, 2006, 8). Badani uczniowie są nastawieni na poszerzanie swojego repertuaru językowego oraz na komunikację międzykulturową, wspomagając się już znanymi językami, a zwłaszcza podobieństwem genetycznym języków: Jeżeli ty umiesz polski i rosyjski język, to spokojnie rozumiesz wszystkie pozostałe słowiańskie [JPII-W].

Uczniowie mieli dokonać samooceny sprawności językowych w zakresie wymienionych języków w stosowanej w szkole skali 10-stopniowej. Średnio najwyżej uczniowie ocenili swoje kompetencje w języku rosyjskim $(8,5)^{3}$, nieco niżej ocenili znajomość języka ojczystego - polskiego $(8,3)$, znacznie niżej języka kraju zamieszkania - litewskiego $(7,5)$, najniżej języka obcego - angielskiego $(6,7)$. W różnych szkołach można dostrzec pewne rozbieżności, uzależnione od otoczenia językowego, z którego pochodzą uczniowie. Wysoka średnia znajomości języka rosyjskiego została podniesiona na skutek wyników w dwu gimnazjach, które znajdują się w oddalonej od centrum dzielnicy Nowa Wilejka (Naujoji Vilnia) oraz w Solecznikach (Šalčininkai), gdzie mieszka dużo ludności rosyjskojęzycznej . Respondenci z tych szkół

\footnotetext{
${ }^{3} \mathrm{O}$ dobrej znajomości języka rosyjskiego mogą świadczyć również wyniki egzaminów maturalnych uczniów szkół polskich w rejonie wileńskim. Egzaminy z języka angielskiego i rosyjskiego mają status egzaminów państwowych i są oceniane w skali 100 punktów. Ogółem uczniowie szkół polskich w tym rejonie uzyskali 55 maksymalnych ocen z egzaminów państwowych, tzw. „setek”. Wśród 272 maturzystów, którzy zdawali język angielski „setki” uzyskały tylko 2 osoby, natomiast „setki” z języka rosyjskiego zdobyło 46 z 235 osób, czyli prawie $20 \%$ zdających ten egzamin. Zob. http://l24. lt/pl/oswiata/item/312836-rekordowa-liczba-setek-w-rejonie-wilenskim (dostęp: 20.08.2019)

${ }^{4}$ Nowa Wilejka (przyłączona do Wilna w 1957 r.) do lat 90 . XX w. była dzielnicą przemysłową, w której mieściło się kilka wielkich zakładów. Industrializacja tej dzielnicy bardzo zmieniła skład demograficzny jej
} 
swoją sprawność w zakresie języka rosyjskiego $(8,9)$ ocenili wyżej niż języka polskiego (w Nowej Wilejce - 8,6, w Solecznikach - 8,02). Ocena znajomości języka polskiego przez uczniów z rejonu wileńskiego była analogiczna jak i rosyjskiego (Niemenczyn - 8,8) lub nawet wyższa (Bujwidze - 8,1 wobec 7,7 w przypadku rosyjskiego). Nieco wyżej swoją sprawność w zakresie polszczyzny ocenili również uczniowie szkoły w Wilnie (8,3 wobec $8,2 \mathrm{w}$ przypadku języka rosyjskiego). Respondenci ze wszystkich szkół tylko na trzecim miejscu pod względem znajomości umieścili język litewski $(7,5)$, któremu tak wiele uwagi poświęca się w szkole. Jak można przypuszczać, najpewniej w tym języku czuje się młodzież z miasta $(7,9)$, która na co dzień jest zanurzona w otoczeniu litewskojęzycznym, najniżej zaś siebie ocenia młodzież z miejscowości wiejskiej $(6,7)$, gdzie kontakt z językiem litewskim w zasadzie ogranicza się do lekcji w szkole. Mimo że deklaracji użytkowników nie można traktować jako obiektywnej oceny, świadczą one o postawach użytkowników i swobodzie posługiwania się poszczególnymi językami. Zaskakujące może się wydawać wynikające z badań przekonanie młodych Polaków litewskich o dobrej znajomości języka rosyjskiego, zwłaszcza że na jego naukę w szkole przeznacza się tylko godzinę tygodniowo. Wyniki te zdumiewają również na tle porównawczym sprzed 20 lat, ponieważ w samoocenie ówczesnych uczniów wypadał on znacznie gorzej5. Dalsze rozważania powinny rzucić światło na okoliczności, które powodują, że w pokoleniu, które urodziło się w niepodległej Litwie i dorastało w Unii Europejskiej, nie zmniejsza się zainteresowanie językiem rosyjskim.

\section{Sposób akwizycji i zakres użycia różnych języków w najbliższym otoczeniu}

Stopień opanowania różnych języków uzależniony jest od sposobu ich akwizycji. W przypadku większości badanych osób mamy do czynienia z wczesną wielojęzycznością symultaniczną - już w wieku przedszkolnym młodzi ludzie w naturalny sposób w otoczeniu rodzinnym i środowiskowym przyswajają nie tylko mówiony wariant języka polskiego (85\% badanych osób), lecz również rosyjskiego (72\%), w mniejszym stopniu litewskiego (47\%), których odmiany ogólnej następnie uczą się w szkole. Dla sporej części jednak nauka języka litewskiego (72\%), podobnie jak i angielskiego (85\%) rozpoczyna się w warunkach lekcyjnych w szkole. Godne uwagi jest to, że jednym ze sposobów opanowania języków rosyjskiego i angielskiego, choćby i w zakresie biernym, jest korzystanie z różnych mediów (telewizja, filmy, Internet, gry komputerowe).

mieszkańców, ponieważ przybyło tu do pracy wiele osób rosyjskojęzycznych z Białorusi. Procesy migracyjne dotknęły też położone przy granicy z Białorusią miasteczko Soleczniki, w którym skutki rusyfikacji do dziś są mocno odczuwalne. W stołecznej dzielnicy Nowa Wilejka rosyjski w przestrzeni publicznej pomyślnie konkuruje z litewskim, a w miasteczku Soleczniki jest dominującym środkiem komunikacji.

5 Na podstawie danych z 1997-1998 lat (Geben 2004, 47-52) w samoocenie badanych wówczas uczniów na Litwie ich kompetencje w zakresie polszczyzny (czynna dobra - 94\%) były znacznie lepsze niż w zakresie języka rosyjskiego (czynna dobra - 76,2\%, czynna słaba - 21,1\%), którego znajomość z kolei oceniano nieznacznie wyżej niż litewskiego (czynna dobra - 74,9\%, czynna słaba - 22,6\%). W innych przeprowadzonych prawie w tym samym czasie badaniach (Sokołowska 2004, 103) wszyscy uczniowie ocenili znajomość języka polskiego na bardzo dobrze, a 76\% procent uznała, że jest to najlepiej opanowany język, po którym znacznie dalej umieściła litewski (bardzo dobrze - 11\%, dobrze - 74\%, zadowalająco - 14\%), a dopiero następnie rosyjski (bardzo dobrze - 11\%, dobrze - 51\%, zadowalająco - 34\%). 
Uwzględniając doświadczenie komunikacyjne młodych ludzi, wyróżniono cztery sfery użycia różnych języków w komunikacji codziennej: rodzinę w wąskim (rodzice, rodzeństwo, dziadkowie) i szerokim znaczeniu (inni krewni), krąg przyjaciół i kolegów w szkole oraz kontakty z rówieśnikami poza szkołą.

Bodajże największe znaczenie $\mathrm{w}$ kształtowaniu się i rozwijaniu sprawności językowych $\mathrm{w}$ środowisku egzolingwalnym ma najbliższe otoczenie - rodzina. Polszczyznę jako jedyny środek komunikowania się $\mathrm{w}$ kręgu najbliższych wskazało tylko 29 uczniów (25\%), w większości przypadków wymieniano dwa lub więcej języków, dwóch uczniów z Solecznik zaznaczyło w tym miejscu język rosyjski. Na podstawie dwu różnych sposobów zaznaczania zakresu użycia różnych języków w rodzinie może wynikać, że wyeksponowana przez samych ankietowanych wielojęzyczność $\mathrm{w}$ rodzinie występuje w dwu formach: alternacyjnego przełączania kodów oraz mieszania języków. Pod alternacyjnym przełączaniem kodów należy rozumieć posługiwanie się w jednym czasie jednym językiem (Auer 1998, 2), którego zmianę powoduje wymiana jakiegoś składnika sytuacji komunikacyjnej, najczęściej interlokutora. Zdarza się to w rodzinach mieszanych, gdy dziecko z każdym z rodziców (lub dziadków) rozmawia w jego języku ojczystym, a zwracając się do innego rozmówcy, zmienia język konwersacji. Posługiwanie się odrębnymi językami w kontaktach z matką i ojcem zaznaczyło 20 osób (18\%), w zdecydowanej większości w takiej koegzystencji w rodzinie spotykały się język polski i rosyjski, tylko w dwu przypadkach chodziło o dwujęzyczność polsko-litewską. Oznaczałoby to, że w heterogenicznych rodzinach polsko-rosyjskich małżonkowie znacznie częściej decydują się na oddanie dzieci do szkoły z polskim językiem nauczania niż w rodzinach polsko-litewskich, w których wybiera się najczęściej edukację w języku państwowym.

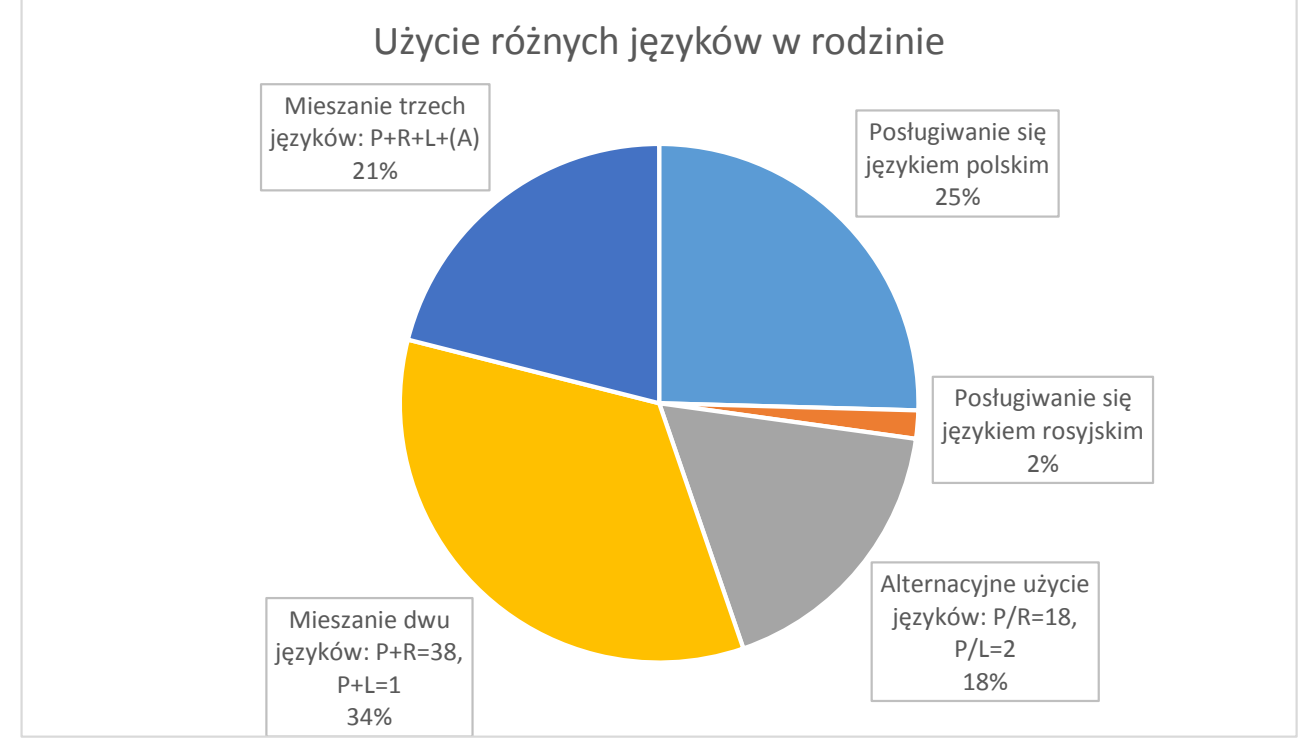

Diagram 1.

W wielu ankietach uczniowie zaznaczali, że różne języki pojawiają się w komunikacji z tymi samymi osobami: $34 \%$ zaznaczyło dwa języki (w 38 
przypadkach chodziło o kombinację polskiego i rosyjskiego i tylko w jednym - polskiego i litewskiego), 21\% wymieniło trzy, a nawet cztery języki, zaznaczając, że angielski pojawia się jedynie w komunikacji z rodzeństwem. Można przypuszczać, że w ten sposób sygnalizowano inne zjawisko charakterystyczne dla społeczności wielojęzycznych - mieszanie kodów, czyli wtrącanie do wypowiedzi w jednym języku wyrazów i połączeń wyrazowych z innego języka, które może stać się charakterystycznym stylem komunikacji nieformalnej w pewnej grupie środowiskowej, manifestacją jej wielokulturowej tożsamości (por. Auer 1998, 3). Tę właściwość można przypisać potocznej polszczyźnie na Litwie, w której często sięga się po materiał z języka rosyjskiego i litewskiego. Z języka litewskiego najczęściej czerpie się nazwy realiów otaczającej rzeczywistości, a z języka rosyjskiego - trafne środki ekspresywne (por. Masojć 2011, 361). Język rosyjski nadal wykazuje wielką żywotność w rodzinach polskich, ponieważ część rodziców badanych osób zna ten język jeszcze z czasów, gdy Litwa była w składzie ZSRR, a niektórzy mogli ukończyć szkołę rosyjską. W środowisku Polaków litewskich ciągle popularne są media rosyjskojęzyczne, a zwłaszcza telewizja. Rosyjskie lub litewskie wtręty leksykalne zaspokajają różne potrzeby, np. uzupełniają sporadyczne braki leksykalne: Wiem polskie słowo, jak to powiedzieć, ale po prostu zapominam (...), to mówię albo po litewsku, albo po rosyjsku [JPII-W], służą różnym celom pragmatycznym: Zdarza się, że $w$ rodzinie możemy po prostu tak dla żartu przejść i na język litewski, i na rosyjski [Parcz-W].

Drugim ważnym środowiskiem językowym są kontakty z rówieśnikami w szkole i poza szkołą. Jeżeli chodzi o język używany w sytuacji nieformalnej w otoczeniu szkolnym, odpowiedzi były następujące: 19\% uczniów deklarowało, że posługują się polszczyzną, większość natomiast przytaczała różne języki, najczęściej wymieniano: polski i rosyjski (34\%), polski, rosyjski i litewski (25\%) lub wszystkie cztery włącznie z angielskim (11\%). Inne kombinacje zostały poświadczone pojedynczo. 2 uczniów ze szkoły w Solecznikach, gdzie dominuje otoczenie rosyjskojęzyczne, uznało, że językiem komunikacji nieformalnej również w szkole jest dla nich język rosyjski.

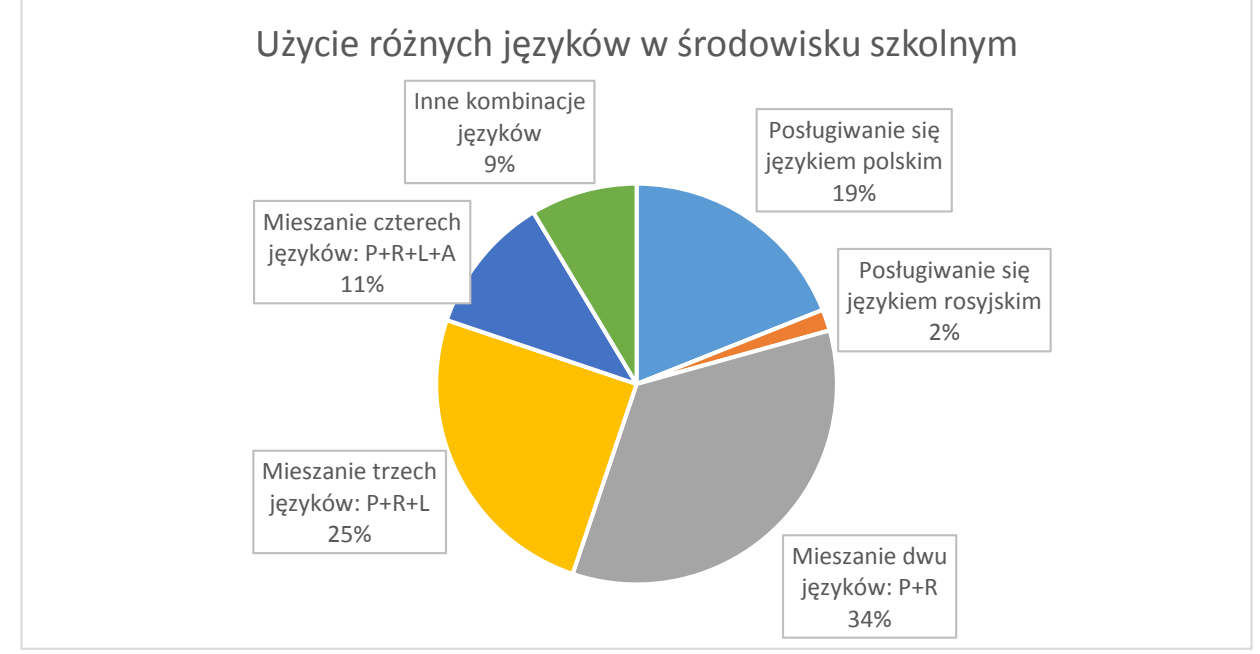

Diagram 2. 
Wywiady z uczniami wyjaśniły, że w porozumiewaniu się w środowisku szkolnym nie chodzi o całościowe przechodzenie z języka na język, lecz o spontaniczne przeskoki kodowe w jednej wypowiedzi. Są one charakterystyczne zarówno dla komunikacji bezpośredniej, jak i zapośredniczonej przez media, gdzie zdaniem uczniów występują ze szczególną intensywnością: $A$ w czatach to tam moga w jednym zdaniu być użyte trzy, cztery języki [Krasz-W], $W$ grupie klasowej to najczęściej bywa tak, że mieszanka języków, bywa jakieś kawały śla po angielsku, odpisujesz po rosyjsku, czy nawet po polsku [Parcz-W]. W kontaktach z kolegami poza szkołą uczniowie posługują się różnymi językami: językiem polskim - 103 osoby, językiem rosyjskim - 99, litewskim - 87, angielskim - 30. Można przypuszczać, że w tym przypadku chodzi o alternacyjne przełączanie kodów w zależności od języka preferowanego przez rozmówcę. Młodzież polskiego pochodzenia w Wilnie, świadoma swojego atutu - wielojęzyczności - chętnie dostosowuje się do języka ojczystego swoich kolegów.

\section{Zróżnicowanie stylistyczne polszczyzny na Litwie}

Młodzi ludzie mają pełną świadomość zróżnicowania stylistycznego polszczyzny na Litwie, osobliwości języka potocznego, ich uwarunkowań i charakteru. Odpowiadając na pytanie, co mają na myśli, posługując się w ankiecie pojęciem „język polski” i mając do wyboru cztery warianty odpowiedzi, najwięcej uczniów zaznaczyło wariant „język ogólny, którym mówią wszyscy Polacy w całym świecie" (57\%), mając na myśli poznawaną przede wszystkim w szkole polszczyznę ogólną, której znajomość włącza ich do wielkiej wspólnoty narodowej. Nieco mniej badanych wybrało, często jednocześnie z poprzednią odpowiedzią, inne opcje: „język mieszany, w którym jest wiele zapożyczeń litewskich i rosyjskich” (49\%), „język regionalny, który cechują pewne odrębności językowe” (37\%), „język niepoprawny, w którym jest sporo błędów" (13\%). Wszystkie trzy warianty odpowiedzi dotyczą odmiany lokalnej polszczyzny. Pierwsze dwa akcentują różne jej parametry - jakościowy i terytorialny, ostatni wyraża postawę wartościującą. Zarówno powyższe wybory uczniów, jak i ich pisemne oraz ustne komentarze świadczą, że za najbardziej charakterystyczną właściwość swojego socjolektu uważają dużą liczbę wtrąceń z innych języków (przede wszystkim rosyjskiego).

Uczniowie najczęściej przeciwstawiają dwa warianty: język ogólnopolski i regionalny, częściej nazywany za pomocą określenia jakościowego „mieszany” niż terytorialnego „wileński”, które traktują synonimicznie, por. Język polski ogólny cechuje poprawność, wyrazy jedynie polskie, a język mieszany („wileński”) cechuje swoista dialektalizacja (sic!), zapożyczenia [Parcz-A]. Odmiana regionalna w odczuciu uczniów jest bardzo zindywidualizowana: Dlatego ten język wileński nie jest stały i dla każdego on jest swój [JPII-W]. Niektórzy zaznaczają, że zróżnicowanie jest uwarunkowane 
sytuacyjnie i/lub pokoleniowo, $\mathrm{np}$. Jest to oczywiste, $\dot{z} e$ w dialogu $z$ osobq wykształcona staram się używać języka ogólnego, poprawnego, z babcia lub ze starszymi często mówię językiem regionalnym (wileńskim), a z kolegami rozmawiam językiem mieszanym [JPII-A]. Niektórzy zatem pod określeniem toponimicznym języka wileński mają na myśli odmianę łączącą wszystkie pokolenia w rodzinie ${ }^{6}$, natomiast socjolekt młodzieżowy najczęściej opisują za pomocą wyrazów mieszany, mieszać, mieszanina. Mieszanie języków jest charakterystyczne dla różnych generacji, w młodym pokoleniu występuje ono jednak ze szczególną intensywnością: Jest coś takiego, jak wpływ innych języków i $w$ naszym pokoleniu jest tego o wiele więcej [Jakich języków?] Rosyjski, litewski, angielski [A w języku rodziców?] Tam już angielskiego na pewno nie ma, tam idzie rosyjski i litewski. Jeszcze starsze pokolenie - tam najbardziej rosyjski [Krasz-W]. Nieformalny styl komunikacji młodzieży uczęszczającej do szkół polskich na Litwie jest na tyle osobliwy, że może być postrzegany przez ich rówieśników z Polski jako odrębny kod: Bo na przykład parę razy byłem $w$ Polsce na wymianie i na przykład jak my rozmawiamy między sobq (...), Polacy pytaja nas: Jaki to język? [Parcz-W].

Slang młodzieżowy na Litwie doczekał się poważniejszych opracowań. Przedstawione w książce M. Dawlewicza $(2000,113)$ wyniki badań ankietowych pokazały, że charakterystyczną cechą socjolektu młodzieży polskiego pochodzenia w Wilnie jest duża liczba zapożyczeń z różnych języków, które stanowiły wówczas 41,87\% całości materiału. Najliczniejszą grupą wśród nich były rusycyzmy - 32\% (841 jednostek leksykalnych), podczas gdy lituanizmów było tylko 2,09\% (54 jednostki leksykalne), a anglicyzmów - 1,5\% (42 jednostki leksykalne). Z podobnych badań powtórzonych po 10 latach wynikało, że liczba obcych jednostek leksykalnych w slangu młodzieżowym zwiększyła się głównie kosztem zapożyczeń rosyjskich, które tym razem stanowiły nawet $44 \%$ zebranego materiału 7 . Zatem już wówczas zanotowano rosnący wpływ języka rosyjskiego na komunikację w polskim środowisku młodzieżowym w Wilnie. Można przypuszczać, że po upływie kolejnych 13 lat proporcje zapożyczeń w slangu uczniowskim mogły ulec kolejnej zmianie, chociaż z niniejszych badań wynika, że język rosyjski nie stracił pozycji dominującej.

\section{Wybory językowe w różnych rodzajach aktywności}

O znaczeniu języka decyduje jego użyteczność w różnych rodzajach działalności uczniów, które w badanym pokoleniu najczęściej są związane

${ }^{6}$ Polskie gwary ludowe na Wileńszczyźnie w drugiej połowie XX w. doznały dynamicznych zmian. Z jednej strony, zaczęły ewoluować w kierunku języka ogólnego, zwłaszcza w języku nowej inteligencji, z drugiej zaś - ulegać rusyfikacji, szczególnie w dziedzinie słownictwa.

7 Zob. Oleńska M., 2008, Ewolucja socjolektu młodzieży polskiego pochodzenia w Wilnie, praca magisterska. Wileński Uniwersytet Pedagogiczny, dostępna w Internecie: http://gs.elaba.lt/object/ elaba:2002547/2002547.pdf (dostęp: 12.10.2019). Wzrost rusycyzmów szczególnie uderzający był na tle porównawczym z lituanizmami, których udział pozostał prawie ten sam - 2,3\%, oraz anglicyzmów, których liczba się zwiększyła do 2,5\%, co prawda, najbardziej licznie była reprezentowana w kręgu tematycznym „Technologie informacyjne”, którego w opracowaniu M. Dawlewicza jeszcze nie uwzględniono. 
z zastosowaniem nowych technologii informacyjno-komunikacyjnych. W Internecie dostępna jest informacja we wszystkich językach, a kontakty mają charakter globalny. Komunikację interpersonalną w sieci zastąpiła komunikacja grupowa, a kontakty międzykulturowe stały się jeszcze bardziej intensywne.

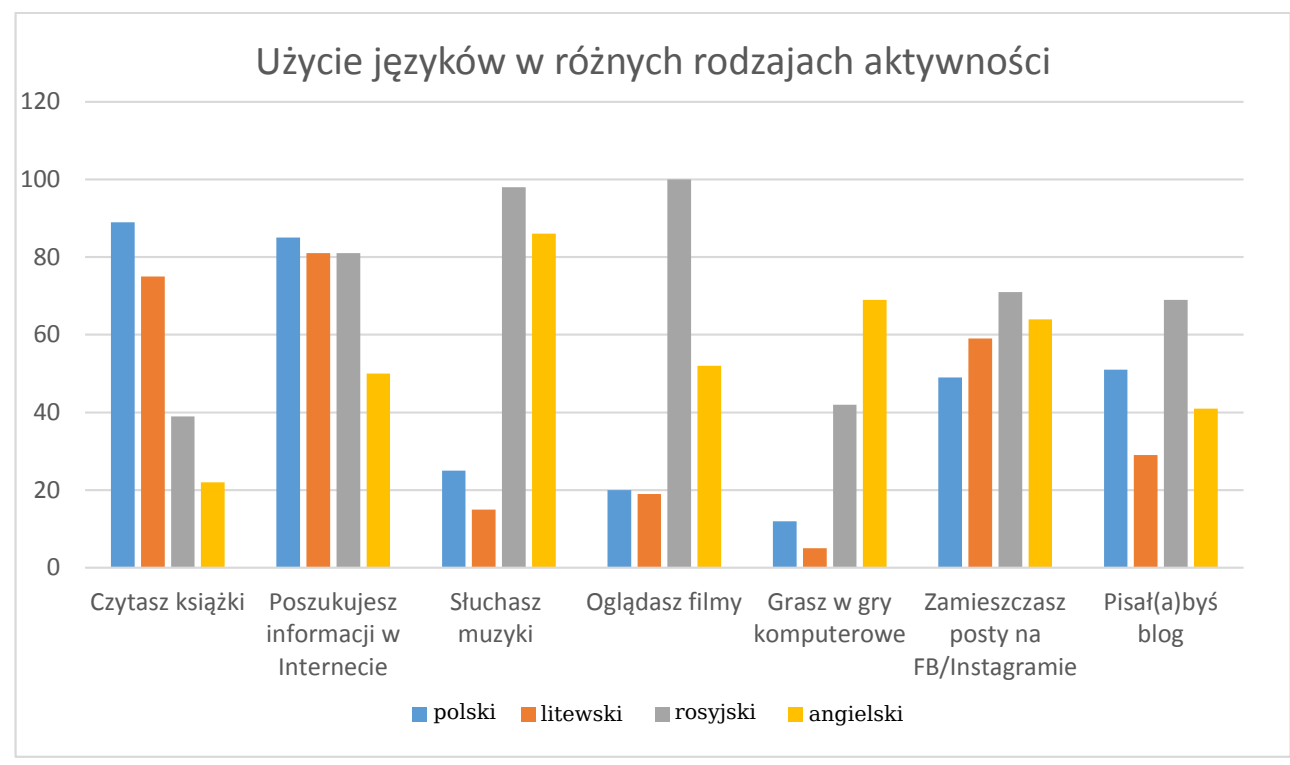

Diagram 3.

Wśród różnych rodzajów działalności uczniów uwzględniono również czytanie książek. Obcowanie z lekturą w wieku szkolnym jest jedną z tradycyjnych form kontaktu z językiem. Jest to jedyna dziedzina, w której dominują dwa identyfikujące Polaków litewskich języki - ojczysty polski i państwowy litewski: 77\% badanych uczniów zadeklarowało, że czyta książki w języku polskim, 65\% - w języku litewskim, 34\% - w języku rosyjskim, 19\% - w języku angielskim. Należy jednak wziąć pod uwagę, że w większości przypadków są to lektury obowiązkowe z języka polskiego i litewskiego, do poznania których uczniowie są zobligowani przez szkolny program nauczania. W przyszłości natomiast preferencje językowe w doborze książek (które coraz częściej mają postać audiobooków lub e-booków) mogą ulec zmianie.

Dzięki znajomości wielu języków badani uczniowie mają zwielokrotniony dostęp do informacji w Internecie i jak wynika z odpowiedzi, najczęściej korzystają ze stron internetowych w różnych językach: język polski wymieniło 73\% respondentów, język litewski i rosyjski - po 70\%, język angielski - 43\%. Wybór języka zależy od celu poszukiwania informacji. Gdy wiąże się on z konkretnym zadaniem szkolnym, uczniowie często wybierają ten język, w którym mają zaprezentować materiał na lekcji. Stwierdzają jednak, że najbardziej bogatym i wiarygodnym źródłem informacji na interesujące ich tematy pozalekcyjne są strony angielsko- i rosyjskojęzyczne, dlatego w dziedzinach rozrywkowych (oglądanie filmów, słuchanie muzyki, korzystanie z gier internetowych) wyraźne pierwszeństwo oddają językowi rosyjskiemu i angielskiemu. Nawet 86\% uczniów zadeklarowało, że ogląda 
filmy w wersji rosyjskiej (czasami jako jedynej), a 84\% - słucha rosyjskiej muzyki popularnej. Nieco mniej osób wybiera filmy w wersji anglojęzycznej (45\%) i słucha muzyki w tym języku (74\%). Podstawowym nośnikiem kultury masowej zatem okazuje się język rosyjski, a przyczyniają się do tego tradycyjne media (telewizja i radio) oraz bezpośredni dostęp do muzyki i filmów rosyjskich (lub zagranicznych w dobrym dubbingu rosyjskim) w Internecie. Język angielski dominuje w grach internetowych $(58,6 \%)$, znacznie wyprzedzając w tej dziedzinie rosyjski (36\%) i spychając na margines polski (10\%) i litewski (4\%).

W mediach społecznościowych uczniowie posługują się tymi językami, które mają szerszy zasięg społeczny. Języki, które ich zdaniem najbardziej się nadają do wpisywania postów na Facebooku lub Instagramie, po zsumowaniu wszystkich odpowiedzi można uszeregować w następującej kolejności: rosyjski (61\%), angielski (55\%), litewski (51\%), polski (42\%). Badani młodzi ludzie oświadczyli, że pisząc blog, również najczęściej posłużyliby się językiem rosyjskim (60\%), choć - inaczej niż w przypadku krótkich komunikatów - na drugim miejscu wymienili język polski (44\%), a nieco dalej angielski (35\%) i litewski (25\%). Ta ostatnia deklaracja świadczy o tym, że większość uczniów jest dobrze oswojona nie tylko z mówioną odmianą języka rosyjskiego, lecz również z alfabetem cyrylickim.

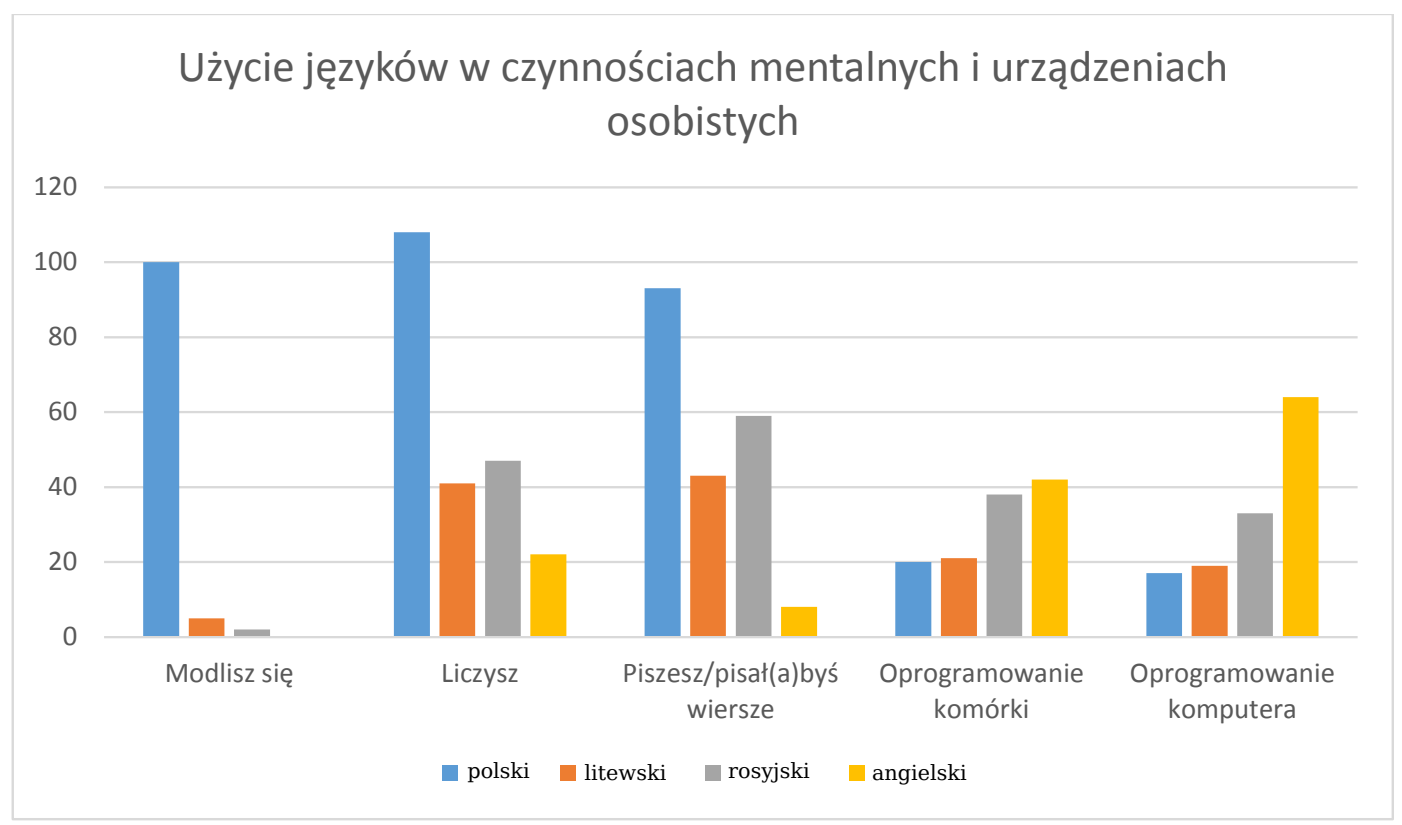

\section{Diagram 4.}

Wydaje się, że dzisiaj nie można już z przekonaniem powtórzyć opartego na badaniach sprzed 20 lat stwierdzenia, że dla młodzieży uczącej się w szkołach polskich na Litwie „polszczyzna bezspornie jest językiem myślenia" (Sokołowska 2004, 76) ${ }^{8}$, ponieważ dla części uczniów przestaje

${ }^{8}$ Taki wniosek wypływał jednoznacznie z wyników badań: 97\% uczniów z różnych szkół Wileńszczyzny uważało wówczas, że z tym językiem wiąże planowanie i snucie projektów, 94\% - pisanie pamiętnika, 93\% - zapisanie przepisu kulinarnego dla własnego użytku, a 94\% używa go w sytuacji zdenerwowania czy strachu (Sokołowska 2004, 75). 
ona być jedynym wyznacznikiem identyfikacji wewnętrznej, która jest istotnym kryterium w definicji języka ojczystego E. Lipińskiej (zob. wyżej). Ta identyfikacja polega na tym, że język ojczysty jako pierwszy jest językiem wewnętrznym jednostki, w którym ona się modli, liczy, myśli itp. Jak wynika z odpowiedzi uczniów, polszczyzna okazuje się bezkonkurencyjna jedynie w sferze modlitwy - 86\% respondentów modli się po polsku, choć 5 osób zaznaczyło również/lub język litewski, a 2 osoby - język rosyjski. W przypadku innych czynności mentalnych różnorodność językowa znacznie się zwiększa. Do liczenia uczniowie w zależności od sytuacji komunikacyjnej używają wymiennie różnych kodów: język polski w tym miejscu zaznaczyło 93\% badanych, język rosyjski - 41\%, język litewski - 35\%, język angielski - 19\%. W wywiadach uczniowie przyznawali sami, że zdarza im się zmieniać również język myślenia, co wiąże się głównie z nauką różnych języków w szkole: Myślę to tė் najczęściej w języku polskim, ale też bywa i rosyjski, i litewski, i angielski, i czasami to robię dla praktyki (...) myślę $w$ tym języku, co i piszę [Parcz-W]. Nie posiadają oni tak wysokich kompetencji językowych, aby mogli swobodnie tłumaczyć z jednego języka na drugi, dlatego często magazynują w umyśle informację w tym języku, w którym ją pozyskali i mają odtworzyć. Z odpowiedzi na pytanie o język, w którym piszą/pisaliby wiersze, wynika, że również przelewanie osobistych uczuć na papier mogłoby przybrać różną postać językową: 80\% wybrałoby w tym celu język polski, ale 51\% - również/lub język rosyjski ${ }^{9}, 37 \%$ - również/lub język litewski, a 8 osób zadeklarowało, że mogłoby podjąć się prób poetyckich w języku angielskim.

$\mathrm{Na}$ język wewnętrzny może mieć wpływ oprogramowanie w osobistych urządzeniach elektronicznych, zwłaszcza w telefonie komórkowym, gdzie wyboru języka można dokonać samodzielnie. Jak wynika z odpowiedzi, młodzież najczęściej wybiera język angielski (36\%) i rosyjski (33\%), dwukrotnie rzadziej decyduje się na język litewski (18\%) lub polski (17\%). Oznacza to, że 1/3 badanych uczniów szkół polskich za pośrednictwem telefonu komórkowego ma stały kontakt z językiem i pismem rosyjskim. Takiej swobody wyboru nie mamy w przypadku oprogramowania w komputerze, która może być ograniczona przez możliwości rynku litewskiego, jednakże odpowiedzi uczniów są bardzo podobne: 55\% uczniów korzysta z oprogramowania w języku angielskim, 28\% - w języku rosyjskim, 16\% - w języku litewskim, $15 \%$ - w języku polskim.

\section{Przydatność języków}

Postawę uczniów wobec języków możemy zaobserwować również na podstawie oceny przydatności języków w dalszym życiu. W ankiecie

\footnotetext{
${ }^{9}$ Wybory uczniów w poszczególnych szkołach nieco się różniły. W szkołach JPII, Parcz i Kon uczniowie zdecydowane pierwszeństwo w tworzeniu tekstu poetyckiego oddali językowi polskiemu. W szkołach Krasz i Śniad, które funkcjonują w otoczeniu rosyjskojęzycznym, uczniowie równie chętnie jak po polski (Krasz - 18 osób, Śniad - 18 osób), sięgnęliby również po język rosyjski (Krasz - 17, Śniad - 17).
} 
uczniowie mieli wskazać języki, których znajomość chcieliby z różnych względów doskonalić i krótko umotywować swój wybór. Na pierwszym miejscu w rankingu przydatności - jak można się było spodziewać - znalazł się język angielski, który wymieniło $91 \%$ respondentów. Uczniowie swoje kompetencje w tym języku ocenili najniżej, jednakże mają pełną świadomość, że sprawność w posługiwaniu się angielszczyzną otwiera przed nimi znacznie szersze perspektywy. Motywacje do nauki tego języka mają głównie charakter pragmatyczny - 56\% badanych uważa, że jest to uniwersalny język międzynarodowy, dzięki któremu będą mogli czuć się komfortowo w zglobalizowanym świecie (swobodnie podróżować i nawiązywać kontakty z różnymi ludźmi), 30\% badanych od znajomości tego języka uzależnia pomyślność swojej dalszej kariery (studiów, pracy zawodowej). Na drugim miejscu pod względem przydatności uplasował się język kraju zamieszkania - litewski, który wymieniło 43\% uczniów. Uzasadnienia w tym przypadku były bardziej zróżnicowane: $24 \%$ kierowało się względami praktycznymi (studia i kariera zawodowa, potrzeba w komunikacji codziennej), w wyjaśnieniach 18 uczniów (16\%) przebrzmiały bardziej lub mniej wyraźne nuty patriotyczne, np. „mieszkam na Litwie”, „język państwowy”, a nawet „język ojczysty" (2 osoby). Z tych deklaracji wynika, że prawie połowa uczniów wiąże swoją przyszłość z Litwą, a część ma nawet emocjonalny stosunek do języka litewskiego. Odpowiedzi na to pytanie pokazują, że pojęcie języka ojczystego w warunkach wielojęzyczności i zamieszkiwania w innym kraju staje się zachwiane, ponieważ pojęcie „ojczyzny” wiąże się zarówno z ojczyzną w sensie symbolicznym, jak i terytorialnym.

Chęć doskonalenia sprawności polszczyzny zaznaczyło $20 \%$ respondentów, a języka rosyjskiego - 21\%. Podstawowa motywacja w przypadku języka polskiego miała podłoże emocjonalne - 9\% wszystkich badanych uczniów uznała, że wymaga on stałej pielęgnacji jako język ojczysty. Korzyści praktyczne wynikające z dobrej znajomości polszczyzny dostrzegło tylko 7 osób (6\%), które chcą podjąć studia w Polsce. Chęć lepszego poznania języka rosyjskiego podyktowana jest względami pragmatycznymi (język przydatny w komunikacji międzykulturowej) lub osobistymi (np. „dla własnej przyjemności").

\section{Wnioski}

W warunkach opisanej wielojęzyczności społecznej i indywidualnej, gdy trzy języki (polski, rosyjski i litewski) są przyswajane w otoczeniu rodzinnym i środowiskowym prawie równocześnie, funkcje i zakres użycia $\mathrm{w}$ komunikacji polszczyzny nie odpowiadają kryteriom, na podstawie których moglibyśmy ją jednoznacznie umieścić w zaprezentowanej na początku typologii. W większości wypadków (odstępstwem są rodziny heterogeniczne językowo) polszczyzna jest językiem pierwszym, a języki litewski i rosyjski to języki drugie. Ich znaczenie zwiększa się jednak wraz 
z wiekiem uczniów: języka litewskiego - na skutek kontekstu socjokulturowego i intensywnej nauki w szkole, a rosyjskiego - w wyniku obcowania z mediami rosyjskojęzycznymi.

Wielojęzyczność badanych uczniów niesie ze sobą zarówno skutki pozytywne, jak i negatywne. Niewątpliwym atutem jest łatwość przechodzenia w zależności od sytuacji komunikacyjnej lub odbiorcy z jednego języka na drugi, czyli alternacyjne przełączanie kodów. Negatywnym zjawiskiem, zwłaszcza z punktu widzenia dydaktyki, jest mieszanie kodów. Taki styl komunikacji nieformalnej panuje w wielu rodzinach, a ze szczególną intensywnością ujawnia się w slangu młodzieżowym, w którym świadomie wykorzystuje się elementy wszystkich czterech znanych języków. Stopień mieszania języków i wachlarz wykorzystywanych języków są bardzo zindywidualizowane. Największy udział w procesie mieszania języków mają charakterystyczne dla wszystkich pokoleń wtręty rosyjskie. Zaskakująco mocna pozycja języka rosyjskiego po 30 latach jego wycofania z przestrzeni publicznej utrzymuje się wskutek ciągłej obecności na Litwie rosyjskojęzycznej kultury popularnej, łatwo dostępnej w nowych mediach. W dyskursie publicystycznym to zjawisko zaczyna się określać mianem rerusyfikacji.

Opis badanego środowiska komplikuje fakt, że językiem odziedziczonym dla wielu uczniów jest odmiana lokalna języka polskiego, którą młodzi ludzie coraz częściej nazywają „językiem mieszanym”. Większość uczniów ogólny wariant języka polskiego opanowuje dopiero w systemie edukacji (przedszkole, szkoła) jako język drugi. Mimo że w szkole jest określany jako ojczysty, nie spełnia wszystkich jego kryteriów zarówno pod względem kompetencji, jak i funkcji (zakresu użycia), w różnych rodzajach aktywności ustępuje miejsce językom drugim (litewskiemu, rosyjskiemu), a nawet obcemu (angielskiemu). Można przypuszczać, że w samoocenie kompetencji w zakresie języka polskiego, uczniowie mieli na myśli polszczyznę ogólną, która w ich odczuciu pozostawia sporo do życzenia. Na przeszkodzie do jego doskonalenia staje zmniejszająca się w starszych klasach liczba godzin lekcyjnych oraz brak motywacji o charakterze pragmatycznym - potrzeby komunikacyjne wewnątrz grupy zaspokaja się najczęściej za pomocą lokalnej odmiany „mieszanej”, a swoją przyszłość i karierę zawodową wiąże się z dobrą znajomością języka angielskiego i litewskiego. Natomiast język ogólnopolski ma dla uczniów głównie wymiar symboliczny - łączy ich z całym narodem i bogatym dziedzictwem kulturowym, którego część zachowała się na Litwie.

Zadania, które stoją przed szkolnictwem polskim na Litwie, polegają na zwiększeniu atrakcyjności polskości i rangi przedmiotu język polski, aby mógł on skuteczniej rywalizować z innymi językami. Na lekcjach języka polskiego powinna być reprezentowana zarówno współczesna kultura wysoka, jak i bliska dla nastolatków kultura popularna, odzwierciedlająca żywą polszczyznę i zdolna stawić czoło zalewowi rosyjskojęzycznej kultury masowej. Jest to jednak temat, który zasługuje na odrębne opracowanie. 


\section{Bibliografia}

Auer Peter, 1998, From Code-switching via Language Mixing to Fused Lects:

Toward a Dynamic Typology of Bilingual Speech. Dostępny online:

http://kops.uni-konstanz.de/bitstream/handle/123456789/3677/470 1.

pdf? sequence $=1$ \&isAllowed =y (dostęp: 13.10.2019)

Dawlewicz Mirosław, 2000, Słownictwo socjolektu młodzieży polskiego pochodzenia $w$ Wilnie, Warszawa.

Geben Kinga, 2003, Świadomość i kompetencja językowa a warstwy leksykalne $w$ idiolekcie młodzieży polskiego pochodzenia na Wileńszczyźnie, Warszawa.

KMPA, 2006 - Kalbų mokymo politikos aprašas. Lietuva. Vilnius: Švietimo aprūpinimo centras. Dostępny online: https://www.smm.lt/uploads/ documents/Archyvas/lt kalbos politika/kalbu politika internetui.pdf (dostęp: 13.10.2019).

Lipińska Ewa, 2003, Język ojczysty, język obcy, język drugi. Wstęp do badań dwujęzyczności, Kraków.

Lipińska Ewa, Seretny Anna, 2013, Nie swój lecz i nie obcy-język odziedziczony $w$ perspektywie glottodydaktycznej. Dostępny online: http://www.euroemigranci. pl/dokumenty/pokonferencyjna/Seretny_Lipinska.pdf(dostęp: 13.10.2019)

Masojć Irena, 2011, Wielojęzyczność Polaków litewskich. Wtręty obcojęzyczne jako wyznaczniki interferencji kulturowej w środowisku wieloetnicznym, w: Nycz R. i in. (red.) Polonistyka bez granic t. 2. Glottodydaktyka polonistyczna - współczesny język polski - językowy obraz świata, Kraków, s. 351-362.

Sokołowska Henryka, 2004, Wielojęzyczność a umiejętności komunikacyjne uczniów szkół polskich na Litwie, Warszawa.

\section{O Autorce:}

Dr Irena Masojć jest docentem w Centrum Języka Polskiego i Kultury Polskiej w Akademii Edukacji Uniwersytetu Witolda Wielkiego. Zainteresowania naukowe: socjolingwistyka, kontakty językowe, metodyka nauczania języka polskiego. Zainteresowania socjolingwistyczne wiążą się głównie z problematyką funkcjonowania języka polskiego $\mathrm{w}$ warunkach wielojęzyczności i wielokulturowości. Najważniejsze publikacje książkowe: Regionalne cechy systemu gramatycznego współczesnej polszczyzny kulturalnej na Wileńszczyźnie (2001), we współautorstwie z J. Riegerem i K. Rutkowską Słownictwo polszczyzny gwarowej na Litwie (2006), we współautorstwie z K. Syrnicką i A. Žičkienè Współczesne polskie pieśni pogrzebowe na Wileńszczyźnie. Antologia (2013). Jest autorką licznych artykułów o specyfice form adresatywnych w polszczyźnie litewskiej. Brała udział w przygotowywaniu elektronicznych zasobów edukacyjnych z języka polskiego dla uczniów na Litwie (2014). Obecnie uczestniczy w międzynarodowym projekcie Polish Online, którego celem jest stworzenie platformy internetowej do nauki języka polskiego. 